\title{
FREQUENCY OF VERTEBRAL FRACTURES IN HIGH-ENERGY TRAUMA
}

\author{
FREQUÊNCIA DE FRATURAS VERTEBRAIS EM TRAUMA DE ALTA ENERGIA \\ FRECUENCIA DE LAS FRACTURAS VERTEBRALES EN TRAUMA DE ALTA ENERGÍA
}

Miguel Ángel Camacho Castillejos', Jose luis Rosas Cadena1, Rita Maria Soledad Valenzuela Romero ${ }^{1,2}$, Emillo Barbarin Rodriguez², luis Muñiz Luna² Christian Camargo Zetina²

1. Hospital Central Cruz Roja Mexicana, Ciudad de México, Mexico.

2. "Hospital deTraumatología y Ortopedia Lomas Verdes" High Specialty Medical Unit, Edo. de México Poniente, Instituto Mexicano del Seguro Social, Mexico.

\begin{abstract}
Objective:Traumatic injuries due to accidents are the leading causes of death and disability in the population of young adults in many countries. Spinal fractures are among the multiple injuries by traumatic mechanisms. The incidence of these injuries is estimated between 8,000 and 16,000 new cases per year and are associated with high-energy trauma. Methods: Retrospective, cross-sectional, descriptive study conducted at the Hospital Central Cruz Roja Mexicana. We reviewed 68 medical records of patients admitted to the emergency department of that hospital and were diagnosed with some type of traumatic vertebral fracture associated with high-energy trauma. Results: The sample consisted of 53 men and 15 women, of whom 11 patients with cervical spine injury, 2 with cervicothoracic injury, 16 with thoracic injury, five with thoracolumbar fracture and 34 with lumbar injury. Conclusions: The lumbar spine is more prone to suffer injuries by high-energy mechanism, followed by the thoracic and cervical spine, respectively. The thoracolumbar junction is more frequently affected than the cervicothoracic junction in a ratio of 2:1. Level of Evidence II; Retrospective studyf.
\end{abstract}

Keywords: Spinal fractures; Indicators / statistics \& numerical data; Health services research; Epidemiology.

\section{RESUMO}

Objetivo: Lesões traumáticas devido a acidentes estão entre as principais causas de morte e incapacidade na população de adultos jovens em muitos países. As fraturas ao nível da coluna vertebral estão entre as múltiplas lesões causadas por mecanismos traumáticos. $A$ incidência dessas lesões é estimada entre 8.000 e 16.000 novos casos por ano, associados com um mecanismo de alta energia. Método: Estudo descritivo, transversal, retrospectivo, realizado no Hospital Central da Cruz Vermelha Mexicana. Foram revisados 68 registros clínicos dos pacientes, que entraram na área de emergência do Hospital Central da Cruz Vermelha Mexicana, diagnosticados com algum tipo de fratura vertebral traumática associada a traumas de alta energia. Resultados: 53 homens e 15 mulheres. 11 pacientes com lesões ao nível da coluna cervical, dois com lesões na região cérvicotorácica, 16 com lesões torácicas, cinco com fraturas na região toracolombar e 34 com lesões na coluna lombar. Conclusões: A coluna lombar é mais propensa a sofrer alguma lesão por um mecanismo de alta energia, seguido pela coluna torácica e a cervical, respectivamente. A junção toracolombar é mais frequentemente afetada que a junção cervicotorácica na proporção de 2:1. Nível de Evidencia II; Estudo retrospectivof.

Descritores: Fraturas da coluna vertebral; Indicadores / estatística \& dados numéricos; Pesquisas sobre serviços de saúde; Epidemiologia.

\section{RESUMEN}

Objetivo: Las lesiones traumáticas por accidentes son las primeras causas de muerte e incapacidad en la población de adultos jóvenes en numerosos países. Entre las múltiples lesiones por mecanismos traumáticos se encuentran las fracturas de columna vertebral. La incidencia a de estas lesiones se estima entre 8.000 y 16.000 casos nuevos por año y son asociados a trauma de alta energía. Métodos: Estudio retrospectivo, transversal, descriptivo realizado en el Hospital Central Cruz Roja Mexicana. Se revisaron 68 expedientes clínicos de pacientes que ingresaron al departamento de urgencias de ese hospital y se diagnosticaron con algún tipo de fractura vertebral traumática asociada a trauma de alta energía. Resultados: La muestra se compuso de 53 hombres y 15 mujeres, de los cuales 11 pacientes con lesión de columna cervical, dos con lesión cervicotorácica, 16 con lesión torácica, cinco con fractura toracolumbar y 34 con lesión lumbar. Conclusiones: La columna lumbar es más propensa a sufrir lesiones por mecanismo de alta energía, seguida de la columna torácica y la cervical, respectivamente. La unión toracolumbar se afecta con mayor frecuencia que la unión cervicotorácica, en proporción de 2:1. Nivel de Evidencia II; Estudio retrospectivof.

Descriptores: Fracturas de la columna vertebral; Indicadores/estadística \& datos numéricos; Investigación en servicios de salud; Epidemiologia.

\section{INTRODUCTION}

Traumatic injuries that result from accidents are one of the main causes of death and disability in the young adult population in many countries. Spinal fractures are included among the multiple complications secondary to traumatic mechanisms.
It is worth mentioning that there are no epidemiological studies of the worldwide incidence of these lesions, but there are series in the United States that report 8,000 new cases annually and others whose figures reach as high as 16,000 cases per year. In the population studied, one variable is the mechanism that produces these injuries, which in most cases are associated with a high-energy trauma. ${ }^{1}$

Study conducted at the Hospital Central Cruz Roja Mexicana, Ciudad de México, Mexico.

Correspondence: Miguel Ángel Camacho Castillejos. Punto fijo No. 50, Fraccionamiento Torres Lindavista, CP 07708, Deleg. Gustavo A. Madero, CDMX, México. E-mail: mike.camacho69@gmail.com 
According to reports in worldwide studies, most spinal fractures occur in the thoracolumbar segment, T12 and L2 being the levels most often affected, probably due to the transition from an existing kyphotic position in the thoracic spine to a position of lordosis adopted by the lumbar spine, making this segment more vulnerable to injuries that are usually accompanied by changes in spinal alignment with important modifications of sagittal balance, neurological compromise, or instability, which is why some of these fractures require surgical management. ${ }^{2}$

The treatment of spinal fractures is constantly evolving; however, certain premises such as the restoration of stability continue to be respected. The patient must be approached systematically in order to minimize the possibility of complications and the fact that most of these injuries result from high-energy trauma with a high risk of damage to the neighboring organs must always be considered. ${ }^{3}$

In the 1980s, most thoracolumbar spine fractures were managed surgically, this treatment having been popularized by the studies conducted by Denis, ${ }^{4}$ however, improved knowledge about the mechanics and stability of the spine broke this paradigm, once again positioning conservative treatment as an alternative for a large number of patients who met certain basic stability criteria despite the presence of a fracture. These injuries were characterized by not compromising the mechanics of the vertebral segment and by maintaining the posterior ligament complex intact, in addition to not having any neurological compromise. There were, however, frequent disc changes in the segments adjacent to the injury, with good clinical and radiographical results. ${ }^{5}$

On the other hand, it is also important to determine the morphology, as well as the mechanism that produced the injury, since damage to the neighboring organs can be as high as that reported by Berstein in 2006, in which the prevalence of intestinal and mesenteric injuries ranged from 38 to $48 \%$ in patients without apparent neurological compromise. This study also reported a high frequency of compression fractures secondary to high-energy mechanisms, reaching $48 \%$ of the total number of patients analyzed, and highlighted the significance of these injuries, since they occur mainly in a young and economically active population. ${ }^{6}$

In the global scenario, Laurer et al. stated that there is a correlation between age, sex, and the cause of the accident and the type and distribution of the fractures, as well as the number of spine fractures that occur with associated injuries, extremely useful information for improving diagnostic and patient care protocols. ${ }^{7}$

Despite the vast knowledge of biomechanics and spinal stability, little is known at the global and national levels about the epidemiology of these injuries, which is why it is important to highlight the growing problem that it represents in our country, as reported in a study conducted at the Hospital de Traumatología y Ortopedia de Lomas Verdes in the state of Mexico, in which most of these injuries were secondary to falls from heights, followed by traffic accidents. The lumbar spine was the most affected segment in this series, with $76 \%$ of the patients with neurological involvement upon arrival at emergency services, ${ }^{8}$ highlighting the key points in which a culture of prevention could have an impact in reducing these injuries and their sequelae.

The objective of this study is to determine the frequency of traumatic spinal injuries in high-energy traumas.

\section{METHODS}

This is a retrospective, cross-sectional, descriptive, socio-epidemiological clinical research study with authorization number 20160601 from the Institutional Review Board of the Cruz Roja Mexicana [Mexican Red Cross] Mexico City headquarters. We reviewed the clinical records of patients admitted to the emergency area of the Hospital Central de la Cruz Roja Mexicana and diagnosed with traumatic spinal fracture associated with high-energy trauma during the period from January 1, 2014 to December 31, 2015. This research study is safe and considered to be of minimum risk according to the norm that establishes the provisions for health research. The informed consent form was not required because it is a retrospective study that evaluates patient records and not individuals. All the data obtained were used only by the investigative team in a way that protected the confidentiality and the identity of the patients.

Spinal injuries were defined as all types of structural alterations resulting from spinal trauma, with the exception of AOSPINE classification type "AO".

High-energy trauma was defined as the exchange of a large amount of energy between two or more bodies during an accidental event that acts against the object, the subject (patient), and their organs. The magnitude of the event may put life, limb, or an organ at risk, since a greater amount of energy is transmitted to the subject in a shorter amount of time, and as a consequence causes structural injuries (fractures, injuries to organs and systems, tissue damage, hypovolemic shock) and biochemical lesions.

\section{RESULTS}

A total of 68 patient medical records were included, of which 53 were men and 15 were women. There were a total of 11 patients with injuries to the cervical spine, 2 patients with injuries to the cervicothoracic spine, 16 patients with thoracic injuries, 5 patients with thoracolumbar fractures, and 34 patients with lumbar spine injuries, this being the most frequently affected location. (Table 1)

In the distribution by age range, 13 patients were in the 14-25 years of age range, 16 in the 26-35 years of age range, this being the most frequent age group, 12 patients in the $36-45$ years of age range, 11 in the 46-55 years of age range, 12 in the 56-65 years of age range, 2 in the 66-75 years of age range, and one patient each in the 76-85 and 86-95 years of age ranges. (Table 2).

As regards the location by age range, 2 patients in the 14-25 years of age range had cervical injuries, none had cervicothoracic injuries, 4 had thoracic injuries, 1 had an injury in the thoracolumbar region, and 6 patients had injuries at the lumbar level. In the 26-35 years of age group, we had 1 patient with a cervical injury, none with injuries at the cervicothoracic level, 3 patients with an injury in the thoracic region, one patient with a thoracolumbar injury, and 11 patients with injuries to the lumbar spine. In the $36-45$ years of age range, there were 3 patients with cervical region injuries, none with cervicothoracic injuries, 2 patients with injuries at the thoracic level, 1 with a thoracolumbar spine injury, and 6 patients with injury to the lumbar region. In the 46-55 years of age range, 2 patients had cervical spine injuries, none had cervicothoracic injuries, 3 had injuries in the thoracic region, none had injuries in the thoracolumbar region, and 6 had lumbar spine injuries. In the 56-65 years of age range, we found 1 patient with injury

Table 1. Distribution of patients by vertebral segment.

\begin{tabular}{c|c}
\hline Vertebral segment & No. of Patients \\
\hline Cervical & 11 \\
\hline Cervicothoracic & 2 \\
\hline Thoracic & 16 \\
\hline Thoracolumbar & 5 \\
\hline Lumbar & 34 \\
\hline Total & 68 \\
\hline
\end{tabular}

Table 2. Distribution of patients by age range.

\begin{tabular}{c|c}
\hline Age range (years) & No. of Patients \\
\hline $14-25$ & 13 \\
\hline $26-35$ & 16 \\
\hline $36-45$ & 12 \\
\hline $46-55$ & 11 \\
\hline $56-65$ & 12 \\
\hline $66-75$ & 2 \\
\hline $76-85$ & 1 \\
\hline $86-95$ & 1 \\
\hline Total & 68 \\
\hline
\end{tabular}


at the cervical level, 2 patients each with injuries at the cervicothoracic, thoracic, and thoracolumbar levels, and 5 patients with lumbar injuries. In the 66-75 years of age range, there were 2 patients with thoracic spine injuries and, in both the 76-85 and 86-95 years of age ranges, we found 1 patient with cervical injuries. (Table 3)

\section{Distribution for females}

Of the 15 women, 3 had cervical spine injuries, none had injuries at the cervicothoracic spine level, 5 had injuries in the thoracic spine, none in the thoracolumbar spine, and 7 had lumbar spine injuries at the , this being the most frequent location. (Table 4)

Regarding the distribution by age range, there were 4 women between the ages of 14 and 25, the most frequent age range, 2 women in the 26-35 years of age range, 3 in the 35-45 years of age range, 2 women in the 46-55 years of age range, 3 between 56 and 65 years of age, and one woman in the 66-75 years of age range. (Table 5)

With respect to location by age range, we found that in the 14-25 years of age range one woman had an injury at the cervical level, none at the cervicothoracic level, two at the thoracic level, none in the thoracolumbar region, and 1 woman had an injury at the lumbar level. Between the ages of 26 and 35, we found no women with injuries at the cervical level, no women with cervicothoracic injuries, 2 women with injuries in the thoracic region, and no women with injuries to the thoracolumbar and lumbar levels. In the 36-45 years of age range, there were 2 women with cervical region injuries, and 1 woman with an injury at the lumbar level. There were 2 women with lumbar spine injuries in the 46-55 years of age range, 3 women with lumbar injuries in the 56-65 years of age range, and 1 woman with a thoracic spine injury in the 66-75 years of age range. (Table 6)

Table 3. Distribution of patients by age and vertebral segment.

\begin{tabular}{c|c|c|c|c|c|c}
\hline \multirow{2}{*}{$\begin{array}{c}\text { Age range } \\
\text { (years) }\end{array}$} & \multicolumn{5}{|c|}{ Vertebral segment } & \multirow{2}{*}{ Total } \\
\cline { 2 - 6 } & Cervical & Cervicothoracic & Thoracic & Thoracolumbar & Lumbar & \\
\hline $14-25$ & 2 & 0 & 4 & 1 & 6 & 13 \\
\hline $26-35$ & 1 & 0 & 3 & 1 & 11 & 16 \\
\hline $36-45$ & 3 & 0 & 2 & 1 & 6 & 12 \\
\hline $46-55$ & 2 & 0 & 3 & 0 & 6 & 11 \\
\hline $56-65$ & 1 & 2 & 2 & 2 & 5 & 12 \\
\hline $66-75$ & 0 & 0 & 2 & 0 & 0 & 2 \\
\hline $76-85$ & 1 & 0 & 0 & 0 & 0 & 1 \\
\hline $86-95$ & 1 & 0 & 0 & 0 & 0 & 1 \\
\hline Total & 11 & 2 & 16 & 5 & 34 & 68 \\
\hline
\end{tabular}

Table 4. Distribution of women patient by vertebral segment.

\begin{tabular}{c|c}
\hline Vertebral segment & No. of Patients \\
\hline Cervical & 3 \\
\hline Cervicothoracic & 0 \\
\hline Thoracic & 5 \\
\hline Thoracolumbar & 0 \\
\hline Lumbar & 7 \\
\hline Total & 15 \\
\hline
\end{tabular}

Table 5. Distribution of women by age group.

\begin{tabular}{c|c}
\hline Age range (years) & No. de Patients \\
\hline $14-25$ & 4 \\
\hline $26-35$ & 2 \\
\hline $36-45$ & 3 \\
\hline $46-55$ & 2 \\
\hline $56-65$ & 3 \\
\hline $66-75$ & 1 \\
\hline $76-85$ & 0 \\
\hline $86-95$ & 0 \\
\hline Total & 15 \\
\hline
\end{tabular}

\section{Distribution for males}

Of the 53 men, 8 had cervical spine injuries, 2 had injuries at the cervicothoracic level, 11 in the thoracic spine, 5 in the thoracolumbar spine, and 27 had lumbar spine injuries, this last being the most frequent location. (Table 7)

In terms of distribution by age range, there were 9 men between 14 and 25 years of age, 14 between the ages of 26 and 35 years of age, this being the most frequent age range, 9 men in each of the $36-45,46-55$, and 56-65 years of age ranges, and 1 man in each of the $66-75,76-85$, and $86-95$ years of age ranges. (Table 8 )

As regards location by age range, we found that in the 14-25 years of age range 1 man had an injury at the cervical level, none at the cervicothoracic level, 2 at the thoracic level, 1 in the thoracolumbar region, and 5 men had injuries of the lumbar spine. In the 26-35 years of age range, we found 1 man with a cervical injury, none with injuries at the cervicothoracic level, 1 man each with thoracic and thoracolumbar injuries, and 11 men with lumbar spine injuries. In the 36-45 years of age range, there was 1 man with a cervical injury, none with cervicothoracic injuries, 2 men with injuries at the thoracic level, 1 man with a thoracolumbar spine injury, and 5 men with injuries in the lumbar region. In the $46-55$ years of age range, 2 men had cervical spine injuries, none had cervicothoracic spine injuries, 3 men had injuries in the thoracic region, none in the thoracolumbar region, and 4 men had injuries to the lumbar region. In the 56-65 years of age group, there was 1 man with a cervical injury and 2 men with injuries at each of the cervicothoracic, thoracic, thoracolumbar, and lumbar levels. In the 66-75 years of age group, there was 1 man with an injury to the thoracic spine, and in both the 76-85 and 86-95 years of age ranges, we found 1 man with a cervical injury. (Table 9)

Table 6. Distribution of women by age and vertebral segment.

\begin{tabular}{c|c|c|c|c|c|c}
\hline \multirow{2}{*}{$\begin{array}{c}\text { Age range } \\
\text { (years) }\end{array}$} & \multicolumn{5}{|c|}{ Vertebral segment } & \multirow{2}{*}{ Total } \\
\cline { 2 - 7 } & Cervical & Cervicothoracic & Thoracic & Thoracolumbar & Lumbar & \\
\hline $14-25$ & 1 & 0 & 2 & 0 & 1 & 4 \\
\hline $26-35$ & 0 & 0 & 2 & 0 & 0 & 2 \\
\hline $36-45$ & 2 & 0 & 0 & 0 & 1 & 3 \\
\hline $46-55$ & 0 & 0 & 0 & 0 & 2 & 2 \\
\hline $56-65$ & 0 & 0 & 0 & 0 & 3 & 3 \\
\hline $66-75$ & 0 & 0 & 1 & 0 & 0 & 1 \\
\hline $76-85$ & 0 & 0 & 0 & 0 & 0 & 0 \\
\hline $86-95$ & 0 & 0 & 0 & 0 & 0 & 0 \\
\hline Total & 3 & 0 & 5 & 0 & 7 & 15 \\
\hline & & & & & &
\end{tabular}

Table 7. Distribution of men by vertebral segment.

\begin{tabular}{c|c}
\hline Vertebral segment & No. of Patients \\
\hline Cervical & 8 \\
\hline Cervicothoracic & 2 \\
\hline Thoracic & 11 \\
\hline Thoracolumbar & 5 \\
\hline Lumbar & 27 \\
\hline Total & 53 \\
\hline
\end{tabular}

Table 8. Distribution of men by age range.

\begin{tabular}{c|c}
\hline Age range (years) & No. de Patients \\
\hline $14-25$ & 9 \\
\hline $26-35$ & 14 \\
\hline $36-45$ & 9 \\
\hline $46-55$ & 9 \\
\hline $56-65$ & 9 \\
\hline $66-75$ & 1 \\
\hline $76-85$ & 1 \\
\hline $86-95$ & 1 \\
\hline Total & 53 \\
\hline
\end{tabular}


Table 9. Distribution of men by age group and vertebral segment.

\begin{tabular}{c|c|c|c|c|c|c}
\hline \multirow{2}{*}{$\begin{array}{c}\text { Age range } \\
\text { (years) }\end{array}$} & \multicolumn{5}{|c|}{ Vertebral segment } & \multirow{2}{*}{ Total } \\
\cline { 2 - 7 } & Cervical & Cervicothoracic & Thoracic & Thoracolumbar & Lumbar & \\
\hline $14-25$ & 1 & 0 & 2 & 1 & 5 & 9 \\
\hline $26-35$ & 1 & 0 & 1 & 1 & 11 & 14 \\
\hline $36-45$ & 1 & 0 & 2 & 1 & 5 & 9 \\
\hline $46-55$ & 2 & 0 & 3 & 0 & 4 & 9 \\
\hline $56-65$ & 1 & 2 & 2 & 2 & 2 & 9 \\
\hline $66-75$ & 0 & 0 & 1 & 0 & 0 & 1 \\
\hline $76-85$ & 1 & 0 & 0 & 0 & 0 & 1 \\
\hline $86-95$ & 1 & 0 & 0 & 0 & 0 & 1 \\
\hline Total & 8 & 2 & 11 & 5 & 27 & 53 \\
\hline
\end{tabular}

\section{DISCUSSION}

In our study, there were 34 patients with lumbar spine injuries, this being the most frequently affected region, which corresponds with reports in the world literature, as established in the studies conducted by both Vaccaro and Stuart, who put the presentation of injuries from $\mathrm{T} 10$ to the sacrum at 33\%, explained as a result of the greater mobility of these segments. It is also important to highlight that in our series the lowest number of injuries were located in the cervicothoracic region, differing somewhat from the other studies, such as that conducted by Leucht in which levels C4 to T2 accounted for $10 \%$ of the injuries.

In the distribution by age range, patients between 26 and 45 years of age had the highest percentage of spinal injuries, being within the figures reported by Leucht in 2009, both for males and females, with the least affected age range of 86-95 years corresponding in a similar manner. This probably corresponds to the type of injury mechanism, since most of these accidents occur by falls from heights and automobile accidents, with young and economically active people being the most susceptible.

On the other hand, the distribution by sex also agreed with the figures reported in numerous series, men being more frequently affected, probably as a result of the type of activities that they perform.

\section{CONCLUSIONS}

The lumbar spine is the most likely segment to suffer a highenergy mechanism injury, followed by the thoracic and cervical spines, respectively. The thoracolumbar junction is affected more often than the cervicothoracic junction at a ratio of 2:1.

Males are more affected by vertebral injuries associated with high-energy mechanisms on a scale of 3.5:1.

Women have a higher incidence between 14-65 years of age, with a peak in the 14-25 years of age group, and men from 14- 65 years of age, with a significant peak in the $26-35$ years of age group. This implies that between the second and third decades of life more risky activities that can cause an accident with a high-energy mechanism are performed.

All authors declare no potential conflict of interest related to this article.

CONTRIBUTION OF THE AUTHORS: Each author made significant individual contributions to this manuscript. MA (0000-0002-6980-175X)*, JL $(0000-0003-2361-5406)^{\star}$, and RM (0000-0002-5104-3516)* were the main contributors to the preparation of the manuscript and contributed to the intellectual concept of the study. MA reviewed the patient medical records and collected the data. JL and EB (0000-0001-7844-1410)* documented the cases in the medical records. MA, JL, and RM conducted the statistical analysis. LM (0000-0003-2363-5589)* and CC (0000-0001-8336-5854)* evaluated the statistical analysis data. MA and EB performed the bibliographical review. LM and CC conducted the final review of the manuscript. ${ }^{*} \mathrm{ORCID}$ (Open Researcher and Contributor ID).

\section{REFERENCE}

1. Vinas CF. Lumbar spine fractures and dislocations. eMedicine Specialties. 2009

2. Whang PG, Vaccaro AR. Thoracolumbar fractures: anterior decompression and interbody fusion. J Am Acad Orthop Surg. 2008;16(7):424-31.

3. Mikles MR, Stchur RP, Grazziano GP. Posterior instrumentation for thoracolumbar fractures. J Am Acad Orthop Surg. 2004;12(6):424-35.

4. Denis F, Armstrong GWD, Searls K, Matta L. Acute thoracolumbar burst fractures in the absence of neurologic deficit. A comparison between operative and non-operative treatment. Clin Orthop Relat Res. 1984;189:142-9.

5. Alanay A, Yazici M, Acaroglu E, Turhan E, Cila A, Surat A. Course of nonsurgical mana- gement burst fractures with intact posterior ligamentous complex: an Mrl study. Spine (Phila Pa 1976). 2004;29(21):2425-31.

6. Bernstein MP, Mirvis SE, Shanmuganathan K. Chance type fractures of the thoracolumbar spine: imaging analysis in 53 patients. AJR Am J Roentgenol. 2006:187(4):859-68.

7. Laurer H, Maier B, El Saman A, Lehnert M, Wyen H, Marzi I. Distribution of Spinal and Associated Injuries in Multiple Trauma Patients. Eur J Trauma Emerg Surg. 2007:33(5):476-81.

8. Muñiz LL, Altamirano MR, MonteroY. Epidemiology of spine trauma in patients with polytrauma. Coluna/Columna. 2017;16(2):121-6. 